\title{
El paisaje. Mímesis, arte y arquitectura
}

\author{
Juan Francisco García Nofuentes \\ Roser Martínez Ramos e Iruela
}

\section{Abstract}

La relación de la arquitectura y la naturaleza se concreta hoy en día a través de la idea de paisaje. Los orígenes del término demuestran cómo la presencia del hombre y la antropización del medio mediante su inexorable papel de agente transformador ha sido un elemento fundamental para entender de forma cabal el territorio natural, atribuyéndole una serie de valores no sólo de índole estético. El paisaje es una entidad que liga indisolublemente naturaleza y arquitectura, naturaleza y sociedad, definiendo una relación de continua ambivalencia entre lo soñado y lo real, hecho que nos conduce al extremo de que el paisaje se puede definir como una interpretación de la percepción, como agente integrador, como moneda de intercambio cultural; en difinitiva como un testigo de la historia y referente de la arquitectura.

La pintura, la literatura, la poesía, la música y la arquitectura han expresado a lo largo de la historia, la importancia y el valor de la contemplación de la naturaleza y su imitación, de percibir y fundir las distintas artes con su esencia, de manifestar un acuerdo profundo de respeto intrínseco al ser humano como ser natural.

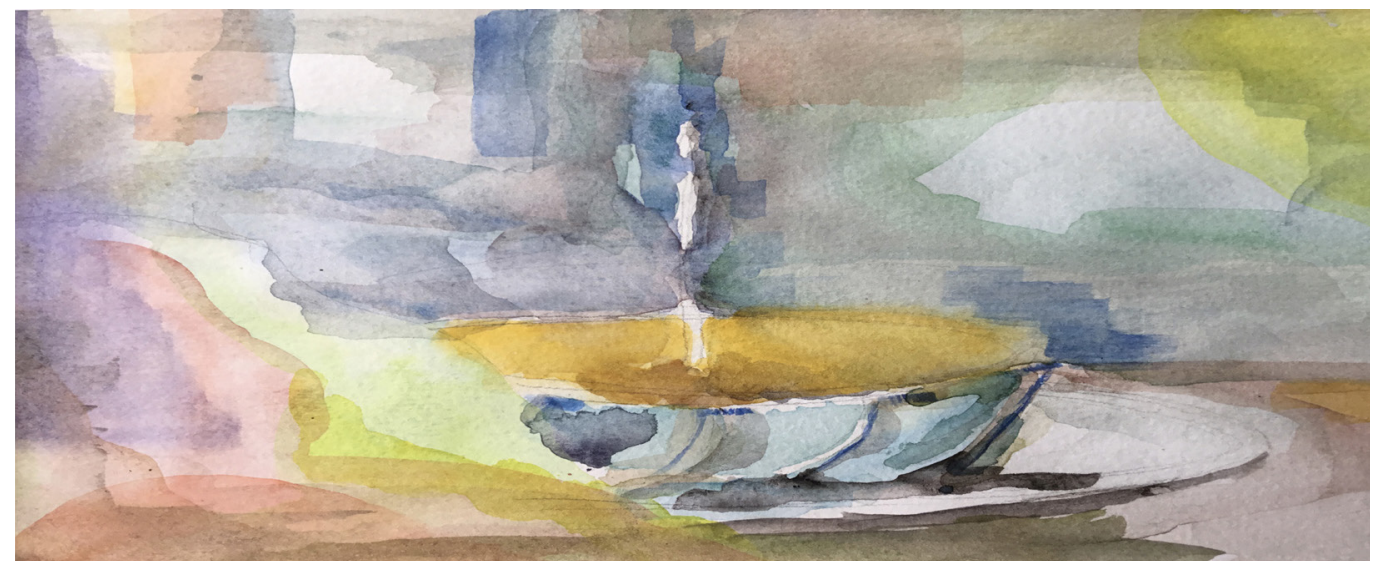




\section{El paisaje como relato contingente del ser humano}

El conocido aforismo que reflexiona sobre cómo el batir de las alas de una mariposa en la selva amazónica pudiera influir sobre las condiciones atmosféricas al punto de poder desatar un posible ciclón en otra parte del planeta, sintetiza la noción de la dependencia sensible de nuestro entorno [Lorenz 1995], según las condiciones iniciales de la teoría del caos que reafirma el continuo estado de mala conciencia de la sociedad post-industrial ante la fragilidad del equilibrio de la naturaleza [I].

Actualmente están en marcha actuaciones en defensa de la naturaleza y la valorización del paisaje, todo ello bajo el escudo protector del marco de una nueva cultura proteccionista de la Naturaleza que se va arraigando en la sociedad actual estimulando de forma masiva a la población para el disfrute de la misma [Baker 1989]. Sin embargo, desde Ruskin, el paisaje es algo definitivamente cultural, no natural, pensamos en ir al encuentro de la Naturaleza y somos espectadores de una obra producida. El paisaje se convierte en un espejo de las relaciones Hombre-Naturaleza.

Durante una conferencia en 1938 el pintor Magritte, dando una explicación sobre su obra La condición humana, declaró "El paisaje es a la vez omisión y conquista del hombre. Así es como vemos el mundo". La pintura representa la superposición de un cuadro sobre la propia escena que describía el cuadro sin posibilidad de distinción entre los dos; es decir sin solución de continuidad. Como interpreta el autor: "lo vemos como si estuviera fuera de nosotros incluso si es una simple representación mental de lo que experimentamos en el interior" [Schama 1997, p. 12]. Lo que está más allá de los vidrios de nuestra percepción mental, dice Magritte, requiere un dibujo antes de que podamos discernir correctamente la forma. Son la cultura, la convención y el acto cognitivo los que forman el dibujo, los que aportan a la retina una impresión de las cualidades que percibimos como belleza. En el paisaje el hombre se vuelve invisible, pero no su mirada. En otras palabras, mirar para el ser humano en general y para el arquitecto y el artista en particular es descubrir, es proyectar y también crear; observar es descubrir y significar, pero también compartir. El paisaje como medio compartido por el hombre y la naturaleza permite combinar todos estos interrogantes (fig. I).

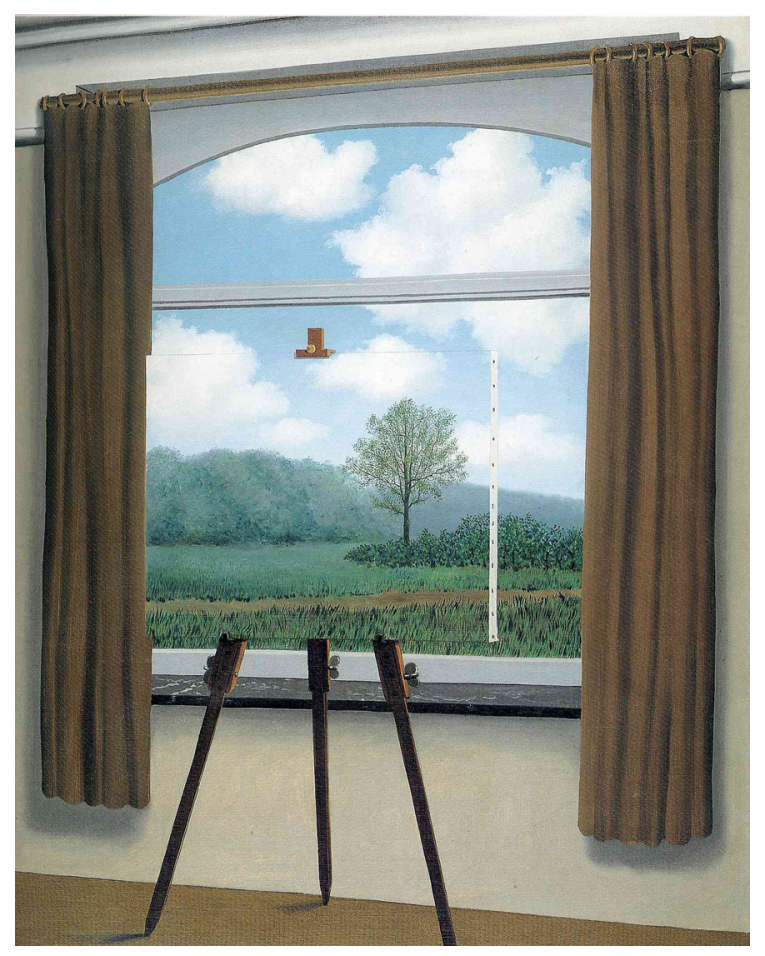


La noción de paisaje en la que el hombre es invisible, se refiere a una concepción estética ligada a la percepción visual y a las sensaciones provocadas tanto por las formas percibidas como por las culturalmente heredadas. El término posee además otras acepciones y matices que derivan de diferentes disciplinas más o menos cercanas, abarcando una gran diversidad de significados en los que la cultura vernácula ejerce su influencia. Por otra parte es necesario diferenciar los conceptos "paisaje y territorio". Éste, se ha identificado tradicionalmente con extensión, con espacio en su acepción euclidiana [Muñoz Serra 2012], siempre bajo una consideración física y una estimación de carácter geométrico. Paisaje lleva implícitas connotaciones estéticas, culturales y sociales.

Es durante el Romanticismo cuando se hace mas evidente la experiencia del paisaje en la pintura y el arte y cuando toma definitivamente protagonismo la denominada "observación con sentimiento". Según palabras de Ritter, "el paisaje se forma concretamente cuando nosotros lo delimitamos a nuestros ojos seccionando la Naturaleza con su infinito simbólico" [Ritter 1994, p. 13]. De igual modo, Cèzanne nos recuerda que la experiencia estética se convierte en un modo de observar las cosas, una actitud subjetiva y emocional del observor "a veces he dudado que la gente de campo sepa qué es un paisaje, qué es un árbol [...] creo verdaderamente que la mayor parte no lo siente, no sabiendo nada fuera de su inconsciente inclinación hacia lo que es útil”' [Gasquet 2005, p. I45].

Fue posteriormente cuando se disoció al observador contemplativo del sujeto dotado de un conocimiento y una capacidad intelectual capaz de garantizar una nueva visión de la naturaleza y del paisaje. Alexander von Humbolt, autor del ensayo Cosmos (20I I), introduce una nueva concepción del paisaje al considerarlo no sólo como algo estético sino también científico.

La llegada de las ciencias positivistas propicia un nuevo cambio en el sentido del término paisaje hasta llegar a convertirse, con los Fundamentos geográficos de Passarge en 1919, en un conjunto de elementos. El estado de ánimo o el estado subjetivo han pasado a ser "materia de conocimiento, reconocible y analizable". A pesar de que hasta los años sesenta prevalece una interpretación estética del paisaje, sostenida por un concepto tardo-idealista de la filosofía, las dos nociones emergentes de la idea paisaje han continuado desarrollándose a lo largo del siglo $X X$, adquiriendo múltiples connotaciones.

La dificultad de establecer de manera unívoca el concepto de paisaje incluyendo la percepción humana arquitectónica, de implantar una definición exhaustiva y convincente, constituye una labor compleja puesto que expresa significante y el significado, simultáneamente y de manera ambigua. Martínez de Pisón ha aportado un buena definición: "El paisaje completo, lleva dentro los ojos del hombre. [...] Esto significa que el paisaje no es totalmente autónomo, totalmente objetivo. [...] La limitación de las visiones parciales o unilaterales del paisaje [...] conduce a un empobrecimiento de su contenido y a que tales imágenes sean compresibles" [Martínez de Pisón 1997, p. 4I].

\section{El paisaje estético como mirada}

El paisaje, tal cual hoy se concibe y se siente en la cultura occidental y mediterránea, ha sido una creación de la pintura. Son las grandes escenas pintadas las que han prefigurado e instaurado el concepto de paisaje pues éste ha sido configurado a través del observador eterno cuya sensibilidad es desarrollada con una preponderante tradición pictórica. Desde época romana existen abundantes muestras dedicadas a la pintura de elementos de la naturaleza. Conocida y reconocida es la serie de ocho pinturas que ilustran la Odisea, descubiertas en 1848 cerca del Esquilino en Roma y conservadas en la Biblioteca Vaticana. Resulta extraordinario el protagonismo que adquieren los planos de fondo con variadas escenas naturales y un esmerado tratamiento de la luz, el espacio y el aire sobre las figuras humanas teóricamente protagonistas de los primeros planos.

El Saltador de Paestum -año 480 a.C.- constituye otra excelente representación para la civilización occidental de la integración de naturaleza-hombre-arquitectura. La excepcional y conocida pintura establece una síntesis de la relación entre naturaleza -el mar y los 
árboles-, arquitectura -el trampolín y el edificio- y el hombre; en una única imagen se integran equilibrio, serenidad y abstracción. La disposición de los diferentes elementos que componen la totalidad del cuadro, constituyen una auténtica foto-fija de indisciplinada belleza. El mar emerge como una perfecta acumulación circular de agua que desborda la parte inferior del marco y que hace dudar acerca de la natural procedencia de la misma. Dos árboles con el nacimiento en diferentes planos acaban por completar una escenografía mitad paisaje mitad arquitectura. Esta última aparece representada en el margen derecho a través de la aparente pesadez de los sillares y por el trampolín sujeto a los mismos; la naturaleza se deja ver, serenamente contenida en el centro de la pintura (fig. 2).

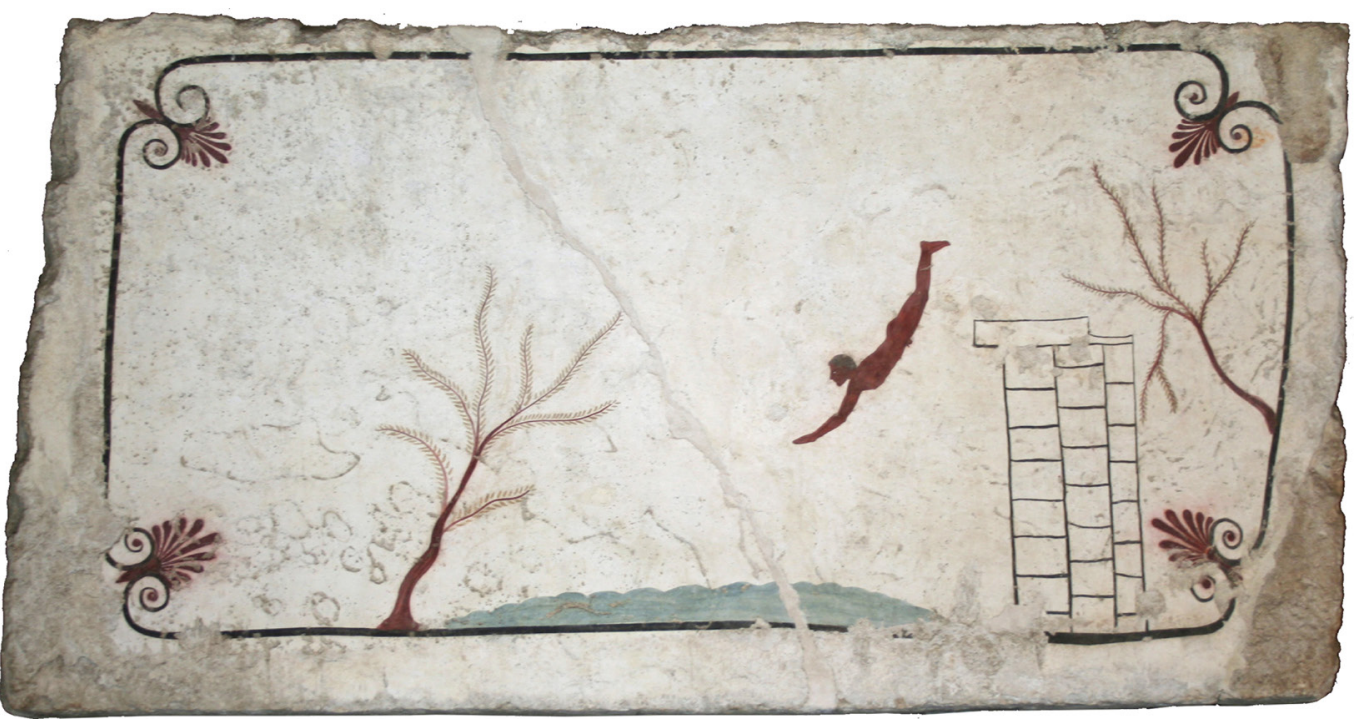

Todos los elementos configuradores del cuadro prefiguran un conjunto único que adquiere un sentido temporal, real e histórico. Podría considerarse como el primer paisaje humano, al ser una combinación integradora del hombre en la realidad; sin embargo, autores como Agustín Berque [2], estiman que a pesar de formar parte de un inestimable conjunto de representaciones pictóricas romanas, de la existencia de determinados pasajes literarios y de la presencia de jardines destinados al placer, en latín nunca existió un término que definiera el concepto de paisaje.

\section{De la representación a la arquitectura como fisura contextualizada en el paisaje}

Dando un paso más, llevamos la cuestión del diálogo con el paisaje al campo de la arquitectura; concretamente al ámbito filosófico y considerando la necesidad de una Hermenéutica del concepto, acudimos a la figura de filósofo fundador de dicha disciplina fiel reflejo de la preocupación universal por la manera en que el hombre de habita y conquista el paisaje.

Martin Heidegger no se ocupa expresamente de arquitectura en Ser y tiempo, su objetivo en esta obra capital, es más bien mostrar cómo dentro de la vida cotidiana y sus contingencias el mundo se abre para mostrar las claves de su funcionamiento.

Haciendo una breve referencia a sus teorías en relación con las 'fisuras de contexto' y la clara relación con la arquitectura y el paisaje sobre todo tras su experiencia italiana a través de la contemplación de numerosas ruinas de templos griegos y romanos, habría que recordar en primer lugar la manera en que en los objetos cotidianos se anuncian explícitamente las referencias y con ellas el mundo. Heidegger muestra cómo el mundo se abre o se revela 
cuando en nuestros hábitos de tratar con las cosas cotidianas, éstos se interrumpen de algún modo, como fisuras en un contexto dado por conocido, sabido y evidente. Cuando el objeto falla, su uso se manifiesta, su para qué se muestra abiertamente al mundo. Existen tres modos cotidianos en que el objeto falla y se manifiesta así su utilidad, tres modos de interrupción de la cotidianidad, circunstancia que nos permite ir más allá de lo habitual y dejar de ver los objetos sólo a medias por su obviedad. Un objeto que se rompe llama la atención por su alteración del orden, se hace evidente por su presencia inútil. Una cosa que resulta necesaria al faltar genera una ausencia, una impertinencia que hace lo que tengo a mano inoportuno, inoperante e ineficaz. Algo que se ha de hacer con urgencia y apremia de manera contumaz, asalta la realidad como una presencia rebelde. Llamatividad - "Auffälligkeit", impertinencia "Aufdringlichkeit" y rebeldía "Aufsässigkeit" constituyen alteraciones, interrupciones y detenciones, del contexto cotidiano. Heiddeger, considerando estas premisas descubiertas en SeryTiempo, se ocupa de la arquitectura y de la obra de arte en general en El origen de la obra de arte [Heiddeger 1950], donde interpreta precisamente la obra de arquitectura como aquella que tiene la capacidad de abrir un mundo en el paisaje [3]. Existe, por tanto una conexión entre la arquitectura y los tres modos de interrupción de la cotidianidad: en ambos casos se abre o se manifiesta el mundo.

Se ofrece, a continuación, la cita literal de la caracterización de la obra arquitectónica, "inspirada en los templos de Paestum", como aquella capaz de abrir un mundo, tal como es expuesta en El origen de la obra de arte, a la luz de esos tres modos de abertura del mundo puestos de manifiesto en Ser y tiempo [Heidegger 1987] (fig. 3).

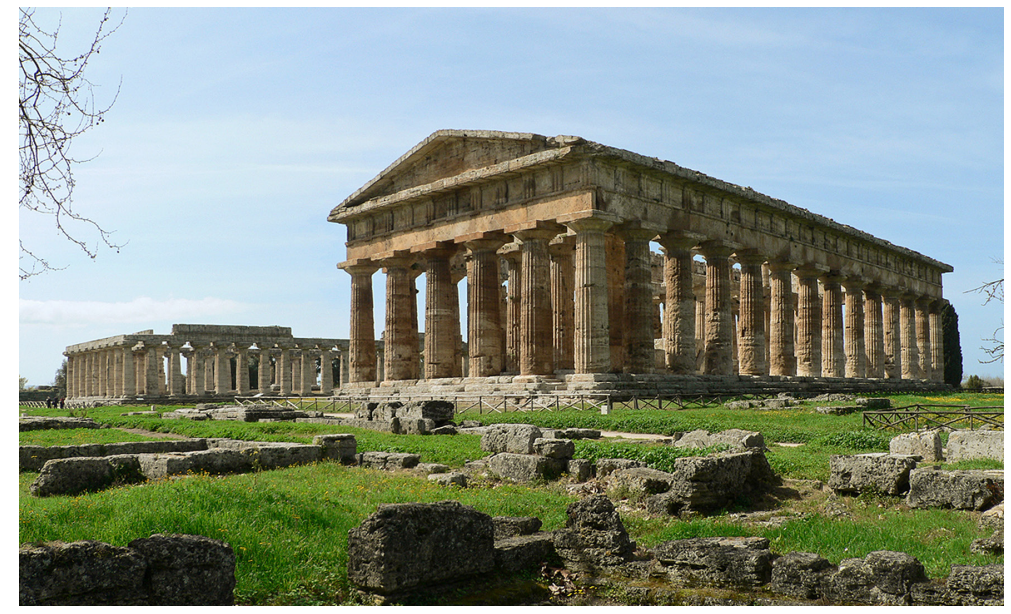

"A la hora de fabricar un utensilio, por ejemplo, un hacha, se usa y se gasta piedra. La piedra desaparece en la utilidad. El material se considera tanto mejor y más adecuado cuanto menos resistencia opone a sumirse en el ser-utensilio del utensilio. Por el contrario, desde el momento en que se instala un mundo, la obra-templo no permite que desaparezca el material, sino que por el contrario hace que se destaque en lo abierto del mundo de la obra: la roca se pone a soportar y a reposar y así es como se torna roca; los metales se ponen a brillar y destellar, los colores a relucir, el sonido a sonar, la palabra a decir.Todo empieza a destacar desde el momento en que la obra se refugia en la masa y peso de la piedra, en la firmeza y flexibilidad de la madera, en la dureza y brillo del metal, en la luminosidad y oscuridad del color, en el timbre del sonido, en el poder nominal de la palabra" [Cortés, Leyte 1996, pp. 34, 35].

El templo atrae la visión sobre sí, sobre su forma y sus materiales, porque no se resuelven en su utilidad, sino que brillan, a diferencia de lo que ocurre con un utensilio como un hacha. Pero no sólo la obra capta nuestra atención sobre sí, sino también sobre el entorno, sobre el paisaje: "Allí alzado, el templo reposa sobre su base rocosa. Al reposar sobre la roca, la 
obra extrae de ella la oscuridad encerrada en su soporte informe y no forzado a nada. Allí alzado, el edificio aguanta firmemente la tormenta [...]. Su seguro alzarse es el que hace visible el invisible espacio del aire" [Cortés, Leyte 1996, p. 33].

En este sentido el edificio levantándose sobre la tierra que lo soporta, se separa y distingue de la tierra viéndose entonces la confrontación del uno contra la otra. Del mismo modo se enfrenta al entorno preexistente, de manera que deja ver a uno y a otro en su diferencia y en su mutua pertenencia. Confrontándose al contexto en vez de someterse a él, la obra de arquitectura representa la luz que nace del pensamiento y que se proyecta sobre el paisaje circundante.

El templo como obra de arquitectura, abre el mundo del pueblo griego, es decir, su presencia se exhibe como una anomalía sobre el paisaje lo que genera una revelación y una confidencia de esa cultura. Haciendo referencia a los tres aspectos contextuales:

I. La obra arquitectónica constituye un accidente que provoca una interrupción del contexto cotidiano, se hace a sí mismo conspicuo, llama la atención y se hace presente "Auffällig". 2. En tanto que inútil, la obra arquitectónica se inserta en un contexto determinado haciendo el contexto mismo impertinente "Aufdringlich". Toda obra de arquitectura pone los edificios del entorno y el entrono mismo a la luz del mundo que ha abierto, uno que no se rige por la funcionalidad.

3. En este sentido la obra es obstinada, rebelde "Aufsässig", no se deja integrar en el contexto dado sin hacer oír su voz.

Los análisis de Heidegger sobre la cotidianidad y los modos en que el mundo se abre en la interrupción de las tareas cotidianas, nos han permitido comprender la obra de arte, la arquitectura en particular y su implantación en el paisaje; en términos de Gadamer (1988), aquella obra que permite abrir un mundo o representarlo.

La metafísica occidental se ha sustentado tradicionalmente sobre una estructura en la que el sujeto es el hombre y el objeto todos los hechos relacionadas con la experiencia sensible. A partir de ciertos hechos históricos acaecidos, la conciencia de crisis de la validez de ese paradigma se extendió a partir del siglo $X X$, por lo que la salida a la crisis se convirtió en una prioridad para las corrientes y escuelas artísticas y filosóficas de la época. En la filosofía contemporánea desaparece casi por completo el principio clásico de la identidad apareciendo la fenomenología con una fuerza extraordinaria gracias entre otros a Norbert-Schulz (1980) y fundamentalmente a la figura de Edmund Husserl, fundador de la "fenomenología trascendental" lo que supone para las doctrinas del siglo XX un proyecto de renovación para convertir la filosofía y las ciencia afines, en ciencia estrictas con un fin colectivo.

\section{Notas}

[I] Es el conocido efecto mariposa descubierto casualmente por Edward Lorenz en 196 I cuando al introducir unas datos atmosféricos en un modelo de predicción meteorológica redondeó de seis a tres decimales y provocó unos resultados de consecuencias impredecibles. Ver: E. N. Lorenz (1995). La esencia del caos. (Trad. esp. F. Páez de la Cadena) Madrid: Debate. (Ed. or. The essence of chaos, 1961).

[2] Estas son las cuatro condiciones que Augustin Berque propone en su artículo Paysage, milieu, historie, para que una sociedad pueda ser considerada paisajista y que tendremos en cuenta a lo largo del análisis histórico de esta tesis. Sin embargo, la interpretación contemporánea que en la actualidad se le da al paisaje en nuestra cultura parece que no sólo cumple sino que supera estas condiciones, abriéndose a nuevos puntos de vista e intersecciones que intentaremos tener también en cuenta: Berque 1994, p. 16.

[3] Der Ursprung des Kunstwerkes es una conferencia pronunciada por primera vez en Friburgo de Brisgovia en 1 935; el epílogo fue escrito parcialmente más tarde y un suplemento añadido en 1956. Se encuentra en la compilación de textos del propio Heidgger Holzwege (1950) en el tomo 5 de la Gesamtausgabe (Frankfurt/M). Hay una traducción castellana: Cortés, Leyte 1996.

\section{Referencias}

Baker Geoffrey (1989). Design strategies in Architecture. An approach to the analysis of form. London: Van Nostrand Reinhold (International).

Berque Agustín (1994). Cinq propositions pour une théorie du paysage. Seyssel: Champ Vallon.

Cortés Helena, Leyte Arturo (1996). El Origen de la Obra de Arte. M. Heidegger 1935-1 936. Madrid, España: Alianza. 
Gadamer Hans-Geor ( 1988). Verdad y método : fundamentos de una hermenéutica filosófica (3a ed.). Salamanca: Sígueme. Gasquet Joachim, Manzano Carlos (2005). Cézanne : lo que vi y lo que me dijo. Madrid: Gadir. Heidegger Martin (1987). El ser y el tiempo (2a ed., 6a reimpr.). México: D.F: Fondo de Cultura Económica. Higueras Arnal Antonio M. (2003). Teoría y método de la geografía: Introducción al análisis geográfico regional. Zaragoza: Universidad de Zaragoza.

Lorenz Eduard (1995). La esencia del caos. Madrid: Istmo.

Martínez de Pisón Eduardo (1997). El paisaje, patrimonio cultural. In Occidente, 194- 195, p. 41.

Ritter Johnatan (1994). El hombre y la naturaleza en la era moderna. Bolonia: Guerini.

Schama Simon (1996). Landscape and memory. New York:Vintage Books.

Von Humboldt Alexander, Rebok Sandra (20I I). Cosmos : ensayo de una descripción física del mundo. Madrid: Consejo Superior de Investigaciones Científicas.

\section{Autores}

Juan Francisco García Nofuentes, Universidad de Granada, jnofuentes@ugres

Roser Martínez Ramos e Iruela, Universidad de Granada, rosermartinez@ugr.es

Para citar este capítulo: García Nofuentes Juan Francisco, Martínez Ramos e Iruela Roser (2020). El paisaje. Mímesis, arte y arquitectura/Landscape. Mimesis, art and achitecture. In Arena A., Arena M., Brandolino R.G., Colistra D., Ginex G., Mediati D., Nucifora S., Raffa P. (a cura di). Connettere. Un disegno per annodare e tessere. Atti del $42^{\circ}$ Convegno Internazionale dei Docenti delle Discipline della Rappresentazione/Connecting. Drawing for weaving relationships. Proceedings of the 42th International Conference of Representation Disciplines Teachers. Milano: FrancoAngeli, pp. $2242-2255$. 


\title{
Landscape. Mimesis, Art and Achitecture
}

\author{
Juan Francisco García Nofuentes \\ Roser Martínez Ramos e Iruela
}

Abstract

Nowadays, the relationship between architecture and nature is layed down through the idea of landscape. The origins of the term, demonstrate how the presence of man and its impact on the environment, through its inexorable role as a transforming agent, has been a fundamental element in fully understanding the natural territory, giving a set of values which are not only of an esthetic nature. Landscape is an entity that firmly bound nature and architecture together, which links nature and society, defining a relationship of continuous ambivalence between the dreamed and the real. This fact lead us to the extreme position of considerating the concept landscape as an interpretation of perception, an integrative agent, a currency of cultural exchange; definitely as a witness of history and a reference of architecture. Painting, literature, poetry, music and architecture have expressed throughout history, the importance and values of nature's contemplation and its imitation, of perceiving and merging the different arts with its essence, of expressing a deep agreement of intrinsic respect for human beings as a natural being.

Keywords

landscape, territory, context, eventuality, Heidegger.

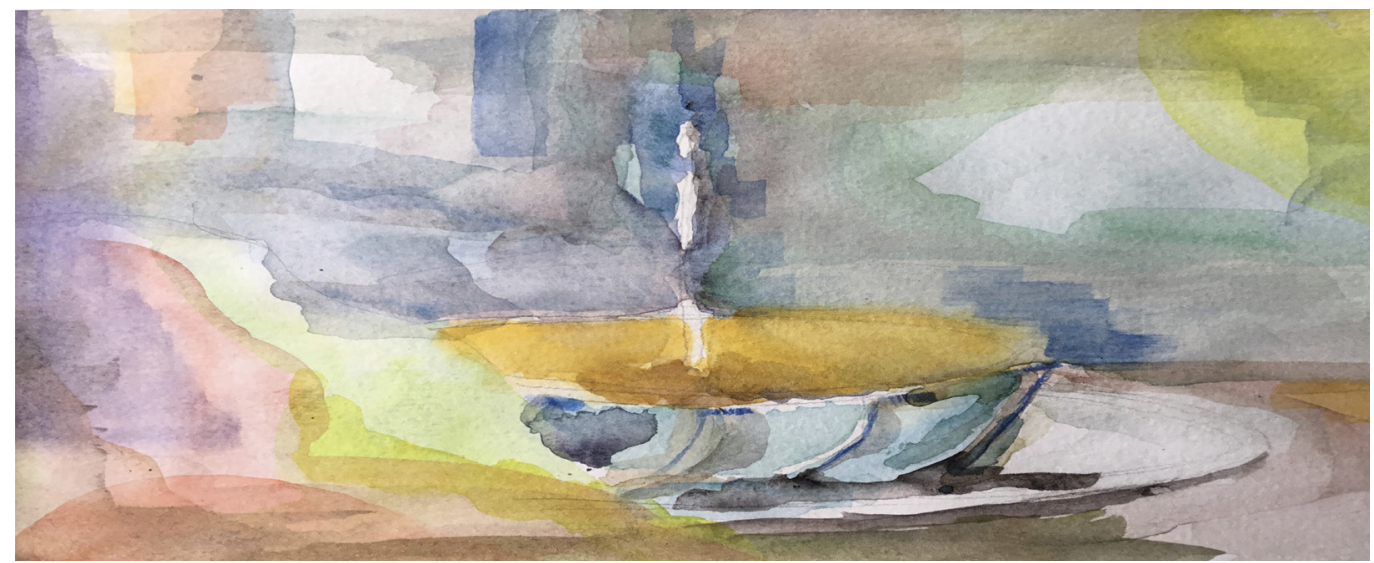




\section{Landscape as contingent story of human being}

The well known aforism of how the flapping of the wings of a butterfly in the Amazon rainforest could affect climate conditions to the point of causing a tornado on another part of the earth syntesises the delicate dependance of our environment [Lorenz 1995], according to the main conditions of the Theory of Chaos, which confirms the continuous lack of conciuosness of postindustrial society concerning the fragility of nature [I].

Nowadays, several measures have been taken to protect and value our landscape, defended and shielded by a new protectionist culture currently expanding, which encourages the importance of enjoying nature [Baker 1989]. Nevertheless, since Ruskin, landscape is indubitably cultural, not natural. We think we discover nature and we are mere observers of a produced work. Landscape becames the glass of the relationship man-nature.

As the painter Magritte was conferencing about his work Human Condition in 1938, he stated: "Landscape is, at the same time, omission and conquest of human. That is how we see the world". The painting represents the superposition of a painting over the scene described on it with no possibility to distinguish any of them, that is, without solution of continuity. As the author says: "We see it as being outside ourselves even though it is only a mental representation of what we experience on the inside" [Schama 1997, p. I2]. What lies beyond the windowpane of our apprehension, says Magritte, needs a design before we can properly discern its form. And it is culture, convention and cognition that makes that design, that invest a retinal design impression with the quality we experience as beauty. In the landscape man becomes invisible, but not his look. In other words, looking, for the human being in general and for the architect and artist in particular, means discovering, projecting and also creating; observing is discovering and signifying, but also sharing. Landscape as a shared mean between man and nature allows the combination of all these questions (fig. I).

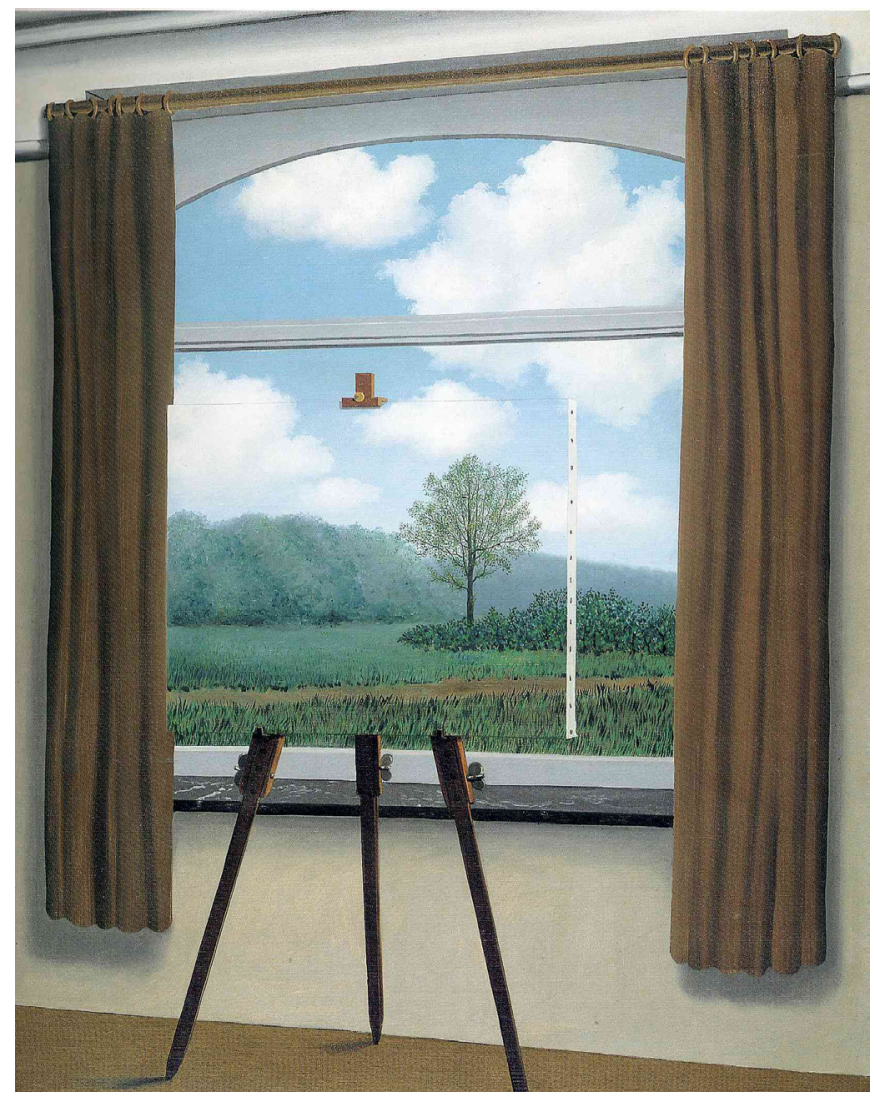


The idea of a landscape where man becomes invisible refers to an aesthetic conception linked to the visual perceptions and sensations produced by both preceived and culturally inherited shapes. This expression has also some other significations and aspects which derive from different disciplines, more or less related, covering a great variety of meanings, driven by the vernacular culture. On the other hand, it is necessary to differentiate the concepts of landscape and territory. The last one has traditionally being related to extension, to space in its euclidean meaning [Muñoz Serra 2012], always through the physical and geometrical consideration of the concept. Landscape implies aesthetics, culture and society.

During Romanticism, the experience of landscape in painting and art becomes more evident. The so-called observation with feeling gains prominence. According to Ritter [Ritter 1994, p. I 3], "landscape derives in concretion when we delimit it to our eyes by sectioning Naure with it infinite symbolic". In the same way, Cèzanne reminds us that the aesthetic experience becomes a way of observing things, a subjective and emotional attitude of the observer: "I have sometimes doubted that they knew what a landscape was, a tree $[\ldots]$ I don't think they feel it or know it outside of their utilitarian unconscious" [Gasquet 2005, p. 145].

It was after that when the contemplative observer was disociated from the individual with the knowledge and intellectual ability to guarantee a new vision of nature and landscape. Alexander von Humbolt, autor of Cosmos (20 I I), introduces a new conception of landscape, considering it not only as an aesthetical but also as a scientific subject.

When positivist sciences appear, a new change arrives in terms of landscape, linking it to the Geographical theories of Passarge in 1919 and creating an ensemble of elements.

The state of mind, or subjective state, becomes an acknowlegeable and analysable subject. Despite the fact that the aesthetical interpretation of landscape has prevailed until the 60 s, based on an idealistic concept of philosophy, both ideas of landscape have been developed along the 20th century, gaining multiple connotations.

The difficulty of establishing an unambiguous concept of landscape, including the human architectonical perception of introducing an exhaustive and convincing definition, is a complex exercise, as it implies signified and signifier at the same time in an ambiguous manner. Martínez de Pisón has come with a good definition: "Landscape as a whole involves the eyes of man [...] This means that landscape is not completely independent, completely objective $[\ldots]$ The limitations of partial or unilateral visions of landscape $[\ldots]$ lead to an impoverishment of its content and the understanding of such images" [Martínez de Pisón 1997, p. 4I].

\section{Aesthetics in landscape as observation}

The concept of landscape, as it is conceived and felt nowadays in western and mediterranean culture, comes from painting.

The great painted scenes have foreshadowed and established it, as they have configured through the eternal observer, whose sensibility rises from a prevalent pictorial tradition. There are numerous samples of paintings representing elements of nature since the Roman Empire.

The series of eight scenes of the Odyssey, well known and recognized, were discovered in 1848 close to the Esquiline in Rome and preserved in the Vatican Library.

The backgrounds of these painings representing natural scenes stand out thanks to a conscientious treatment of light, space and air around the human figures in the foreground, main subject in theory.

The Tomb of the Diver -480 b.C.- is an excelent representation of how western civilization integrates nature-human-architecture. The exceptional and well-known painting synthesises the relationship between nature -the sea and the trees-, architecture, -the springboard and the building- and the human. Balance, serenity, and abstraction are integrated in one image. The disposition of the different elements in the painting becomes a 
genuine picture with oral and undisciplined beauty. The see rises as a perfect circular mass of water which overflows the frame, making us doubt if it is real.

Two trees at different levels complete the scenography which is half landscape and half architecture. This last one is represented on the left side through the heaviness of the ashlar and the springboard above them, nature appears in the middle, quietly reserved (fig. 2).

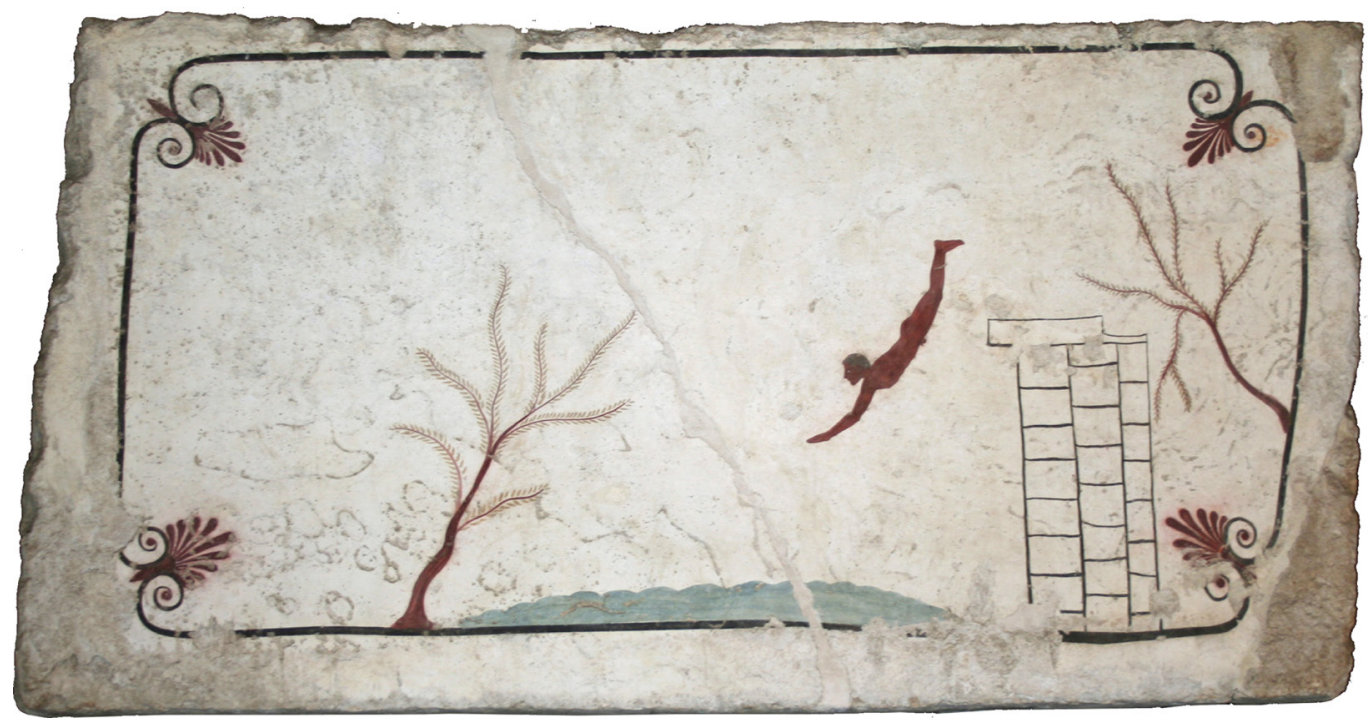

Every configuring element of the painting prefigure one unique ensemble with one temporary, real and historical meaning. It could be considered as the first human landscape, as it is an integrated combination of human in reality. Yet, some authors like Agustín Berque [2] consider that, despite being part of an invaluable piece of roman pictoric representations, of the existance of specific literary landscapes and the presence of gardens dedicated to pleasure, it never existed a latin word to define the concept of landscape.

\section{From representation to architecture as a contextualized fisure in the landscape}

Going a step forward, we take the topic of the dialog with the landscape to the field of architecture; more precisely to the field of philosophy considering the need of an hermeneutic of the concept, we go back to the figure of the founder philosopher of this discipline, faithful reflection of the universal concern about the way the human being lives and conquers the landscape.

Martin Heidegger does not focus explicitly on architecture on Being and Time, his aim in this main work, is rather showing how the world opens to show the keys of its functioning in the ordinary life and its eventualities.

Looking into his theories regarding 'contextual fissures' and the clear relationship with architecture and landscape, mainly after his italian experience through the thoughtfulness of numerous ruins of Greek and Roman temples, we should remember in the first place, how everyday objects announce explicit references and, with them, the world. Heidegger shows how the world opens or reveals itself when our habits and everyday lifes are interrupted somehow, like fissures in a given, known and clear context.

When the object fails, its use is embodied, its what for shows openly to the world.

There are three quotidian ways in which the object fails and hence its usefulness.

Three ways of interruption of ordinariness, a circumstance that allows us to go beyond the usual and to stop seeing objects only halfway due to their truism. An object that breaks draws attention due to the disruption and becomes clear due to its useless presence. 
When something is needed, when it is not there, it creates an absence, a non-belonging, which makes what one has at hand inappropriate, inoperative and inefficient. Something that has to be done urgently, and in a recalcitrant way, struck reality like a rebellious presence. Conspicuousness "Auffälligkeit", obtrusiveness "Aufdringlichkeit" and recalcitrance "Auffässigkeit" are part of alterations, interruptions and detentions of the ordinary context. Considering these premises discovered in Being and Time, Heidegger treats architecture and the artwork in general in The Origin of the Work of Art (Heidegger 1950), where he precisely interprets the architectural work as the one that is capable of opening a world in the landscape [3]. There is then, a connection between architecture and the three ways of interrupting the ordinary: in both cases the world opens and manifest itself. We present now the traduction of the quotation of characterization of the architectural work -Inspired in Paestum temples- as the one capable of opening a world, as it is reflected in The origin of the Work of Art, following these three ways of opening up to the world evidenced in Being and Time [Heidegger 1987] (fig. 3).

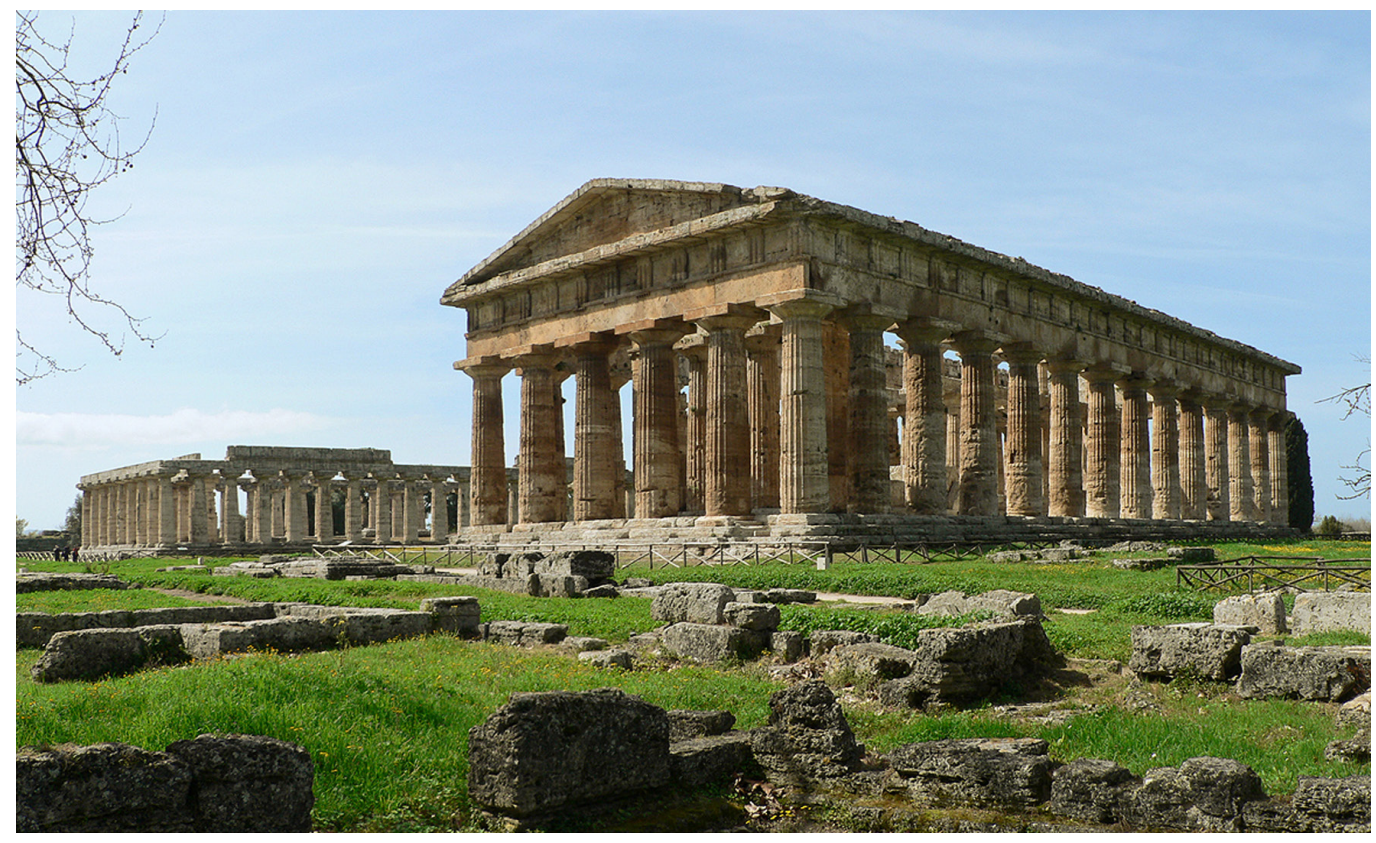

"When manufacturing for example, an axe, the stone is used and consumed. It disappears into usefulness. The less resistance the material puts up to being submerged in the equipmental being of the equipment, the more suitable and the better it is. On the other hand, from the moment a world is set up, the temple work does not let the material disappear; rather, it allows it to stand out, to come forth, that is, into the open world of the work. The rock bears and rests and so first becomes rock; the metal glitters and shimmers, the colours shine, the sounds ring, the world speaks. All this comes forth as the work sets itself back into the massiveness and heaviness of the stone, into the firmness and flexibility of the wood, into the hardness and gleam of the ore, into the lightning and darkening of color, into the ringing of sound and the naming power of the Word" [Cortés, Leyte 1996, pp. 34, 35].

The temple brings attention to itself, to its shape and materials, because they do not resolve in usefulness, but in glow, unlike of what happens with a tool like an axe. Not only has the work attracted the attention towards itself, but towards the environment, towards the landscape: 
"Standing there, the building rests on the rocky ground. This resting of the work draws out of the rock the darkness of its unstructured yet unforced support. Standing there, the building holds its place against the stone $[. .$.$] the temples firm towering makes visible the$ invisible space of the air". [Cortés, Leyte 1996, p. 33].

The temple as an architectural work expands the world of the greek population as it presence means an anomaly on the landscape, which constitutes a revelation and belief of such culture. Analysing the three contextual aspects:

I. Architectural work constitutes and accident which produces an interrumption of the daily context, makes itself notable, present "Auffällig" and stands out.

2. As useless, the architectural work is inserted in a specific context, making the context itself obtrusive "Aufdringlich". Every architectural work exposes and enthrones the buildings inside a new world, one which is not driven by functionality.

3. In this way, the work is obstinate, rebellious "Aufsässig", it does not let itself be integrated in its context without being unseen.

Heidegger's analysis of being and the ways how the world results on an interrumption of everyday tasks allows us to understand the artwork, architecture in particular and its introduction into landscape. As Gadamer (1988) said, that work which opens-up or represents a new world.

Western metaphysics is originally based in a structure where the human is the subject and the facts related to his sensitive experience is the object. Based on certain historical facts, this paradigm became invalid along the 20th century, then the exit from this crisis became a priority to the artistic and philosophical schools of that time. The classical principle of identity almost disappears on modern philosophy, where phenomenology rises with great strenght thanks to Norbert-Schulz (1980) among others, and specially to Edmund Husserl, founder of transcendental phenomenology, leading to a renovation project for the doctrines of the 20th century which will transform philosophy and science into strict sciences with a collective purpose.

\section{Notes}

[I] The well-known butterfly effect was discovered by chance by Edward Lorenz in 196I, when he introduced some atmospherical data in a predictive modeling, rounded up from six to three decimal values and it resulted into unpredictible consequences. See: E. N. Lorenz (1961). The Essence of Chaos. Massachusetts 1961.

[2] These are the four conditions proposed by Augustin Berque in his article Paysage, milieu, histoire, for a society to be considered landscapist and taking into account along the historical analysis of this dissertation. However, the modern and current intepretation of landscape in our culture seems not only to meet but also exceed these condictions, opening to new points of view and intersections which we try to keep in mind: Berque 1994, p. 16.

[3] Der Ursprung des Kunstwerkes is a lecture, first given in Freiburg im Breisgau in 1935. The epilogue was partially written some time after and a supplement was added in 1956. It can be found in a compilation of texts by Heidegger Holzwege himself (1950) volume 5 of Gesamtausgabe (Frankfurt/M).

\section{References}

Baker Geoffrey (1989). Design strategies in Architecture. An approach to the analysis of form. London: Van Nostrand Reinhold (International).

Berque Agustín (1994). Cinq propositions pour une théorie du paysage. Seyssel: Champ Vallon.

Cortés Helena, Leyte Arturo (1996). El Origen de la Obra de Arte. M. Heidegger 1935- 1936. Madrid, España: Alianza.

Gadamer Hans-Geor (1988). Verdad y método : fundamentos de una hermenéutica filosófica (3a ed.). Salamanca: Sígueme.

Gasquet Joachim, Manzano Carlos (2005). Cézanne : lo que vi y lo que me dijo. Madrid: Gadir.

Heidegger Martin (1987). El ser y el tiempo (2a ed., 6a reimpr.). México: D.F: Fondo de Cultura Económica.

Higueras Arnal Antonio M. (2003). Teoría y método de la geografía: Introducción al análisis geográfico regional. Zaragoza: Universidad de Zaragoza.

Lorenz Eduard (1995). La esencia del caos. Madrid: Istmo. 
Martínez de Pisón Eduardo (1997). El paisaje, patrimonio cultural. In Occidente, 194- 195, p. 4 I.

Ritter Johnatan (1994). El hombre y la naturaleza en la era moderna. Bolonia: Guerini.

Schama Simon (1996). Landscape and memory. New York:Vintage Books.

Von Humboldt Alexander, Rebok Sandra (20I I). Cosmos : ensayo de una descripción física del mundo. Madrid: Consejo Superior de Investigaciones Científicas.

\section{Authors}

Juan Francisco García Nofuentes, Universidad de Granada,jnofuentes@ugres

Roser Martínez Ramos e Iruela, Universidad de Granada, rosermartinez@ugr.es

To cite this chaper. García Nofuentes Juan Francisco, Martínez Ramos e Iruela Roser (2020). El paisaje. Mímesis, arte y arquitectura/ Landscape. Mimesis, art and achitecture. In Arena A., Arena M., Brandolino R.G., Colistra D., Ginex G., Mediati D., Nucifora S., Raffa P. (a cura di). Connettere. Un disegno per annodare e tessere. Atti del $42^{\circ}$ Convegno Internazionale dei Docenti delle Discipline della Rappresentazione/Connecting. Drawing for weaving relationships. Proceedings of the 42th International Conference of Representation Disciplines Teachers. Milano: FrancoAngeli, pp. $2242-2255$. 